\title{
WAVE2 Protein Complex Coupled to Membrane and Microtubules
}

\author{
Kazuhide Takahashi \\ Molecular Cell Biology Division, Kanagawa Cancer Center Research Institute, Yokohama 241-0815, Japan \\ Correspondence should be addressed to Kazuhide Takahashi, ktaka@gancen.asahi.yokohama.jp
}

Received 18 May 2011; Revised 12 October 2011; Accepted 17 October 2011

Academic Editor: Dominic Fan

Copyright (C) 2012 Kazuhide Takahashi. This is an open access article distributed under the Creative Commons Attribution License, which permits unrestricted use, distribution, and reproduction in any medium, provided the original work is properly cited.

E-cadherin is one of the key molecules in the formation of cell-cell adhesion and interacts intracellularly with a group of proteins collectively named catenins, through which the E-cadherin-catenin complex is anchored to actin-based cytoskeletal components. Although cell-cell adhesion is often disrupted in cancer cells by either genetic or epigenetic alterations in cell adhesion molecules, disruption of cell-cell adhesion alone seems to be insufficient for the induction of cancer cell migration and invasion. A small GTPbinding protein, Rac1, induces the specific cellular protrusions lamellipodia via WAVE2, a member of WASP/WAVE family of the actin cytoskeletal regulatory proteins. Biochemical and pharmacological investigations have revealed that WAVE2 interacts with many proteins that regulate microtubule growth, actin assembly, and membrane targeting of proteins, all of which are necessary for directional cell migration through lamellipodia formation. These findings might have important implications for the development of effective therapeutic agents against cancer cell migration and invasion.

\section{Introduction}

The cell adhesion molecule E-cadherin is among the key molecules in the formation of the epithelial junctional complex [1-3]. E-cadherin forms homodimers in the extracellular domain between adjacent cells [4] and interacts intracellularly with a group of proteins collectively named catenins $[5,6]$. Both the cadherin cytoplasmic domain and the associated catenins are required for full cell adhesion $[7,8]$, and $\alpha$-catenin is suggested to play a role in anchoring the cadherin-catenin complex to actin-based cytoskeletal components that include $\alpha$-actinin and vinculin [9]. Loss or significant reduction of E-cadherin expression has been observed in many epithelial cancers [10-14], and the $\alpha$ catenin gene is occasionally lost $[14,15]$ or mutated in human cancer cells lines [16]. Unlike E-cadherin and $\alpha$ catenin, $\beta$-catenin loses its function upon tyrosine phosphorylation in response to growth factors $[17-20]$ or $\mathrm{v}-\mathrm{Src}[21$, $22]$. Tyrosine phosphorylation of $\beta$-catenin results in loss of anchoring of the E-cadherin-catenin complex to the network of actin filaments (F-actin) [23, 24]. In normal epithelial cells in culture, tyrosine-phosphorylated $\beta$-catenin needs to be dephosphorylated in order to link the E-cadherincatenin complex to F-actin. In fact, several protein tyrosine phosphatases (PTPs), including DEP-1, PTP1B, and $\mathrm{PTP} \mu$, are upregulated with increasing cell density [25, 26], and they associate with the E-cadherin-catenin complex [2731]. Therefore, constitutive tyrosine phosphorylation of $\beta$ catenin and concomitant loss of PTP might cause loss of Ecadherin-mediated cell-cell adhesion in cancer cells.

Another mode of dysfunction of cell-cell adhesion is induced by perturbation of F-actin assembly to which the E-cadherin-catenin complex anchors. IQGAP1, the IQ moti-containing guanine nucleotide-activating protein 1 (IQGAP1) [32], is an actin cross-linking protein [33, 34] or scaffold protein [35]. IQGAP1 is recruited by protein phosphatase (PP) 2A to the E-cadherin-catenin complex that is constitutively associated with the small GTP-binding protein Rac1 [36, 37], thereby leading to rearrangement of F-actin by IQGAP1 in corporation with Rac1 to which the E-cadherin-catenin complex anchors. Because inhibition of PP2A activity or loss of PP2A expression results in E-cadherin endocytosis [37, 38], PP2A is considered to be involved in the establishment and maintenance of Ecadherin-mediated cell-cell adhesion as well as in a wide variety of biological processes such as tumor suppression [39-41], formation of tight junctions [42], and integrinmediated cell-substratum adhesion [43-48]. Loss of cellcell adhesion due to the internalization or endocytosis of E-cadherin without significant alterations in E-cadherin 
expression has been observed in many cells [38, 49-52]. Despite this, PP2A expression is lost in both invasive and noninvasive cancer cells [38]. This implies that the loss of cell-cell adhesion is necessary but insufficient alone for cell migration and invasion.

In this paper, we focus on recent advances in the understanding of the mechanisms underlying regulation of cell migration and invasion that have been possible through the use of biochemical and pharmacological approaches.

\section{Regulation of Cell Migration}

Cell migration and invasion generally require rearrangement of F-actin at the leading edge of cells [53] and are associated with the formation of specific cellular protrusions termed lamellipodia or filopodia [54]. Rearrangement of F-actin is directed by the Arp $2 / 3$ complex through induction of nucleation and branching of F-actin [54-56] and is regulated by small GTP-binding proteins such as Racl and Cdc42 [57] through Wiskott-Aldrich syndrome protein (WASP) and WASP verprolin homology proteins (WAVE) $[55,58-$ 62]. N-WASP is a member of the WASP family of proteins $[58,60]$ and is thought to be necessary for lamellipodia formation [63]. WAVE family proteins, including WAVE1, -2 , and $-3[58,61]$, induce both lamellipodia [64-66] and filopodia [67]. Among the WASP/WAVE family, WAVE2 has been the most intensively investigated and has been identified as functioning downstream of $\operatorname{Rac}[68,69]$.

Although direct interaction between Rac1 and WAVE2 is not detected in human breast cancer cells, Rac1 forms a complex with CLIP-170, a microtubule-binding protein $[70,71]$, an actin cross-linking protein IQGAP1 $[33,34]$, and kinesin-1, one of the major motor proteins [72, 73], under the growth-arrested conditions [74] (Figure 1(a)). CLIP-170 and IQGAP1 bind microtubules and F-actin, respectively, and kinesin-1 transports many cytoplasmic vesicles, proteins, and mRNAs as "cargo" toward the growing plus-ends of microtubules. Therefore, formation of the Rac1, CLIP-170, IQGAP1, and kinesin-1 complex induces linking of Rac1 to both F-actin and microtubules by IQGAP1 and CLIP170 , respectively $[74,75]$. Depletion of CLIP-170 expression causes growth factor-independent dissociation of IQGAP1 and kinesin-1 from Rac1 and the promotion of random lamellipodia formation and invasion [74]. This suggests that CLIP-170 may play a role in preventing cells from growth factor-independent lamellipodia formation and invasion, by tethering IQGAP1 and kinesin-1 to Rac1 until stimulation by growth factors. Following the stimulation of cells with growth factor, IQGAP1 and kinesin-1 dissociate from the Rac1-CLIP-170 complex [74] (Figure 1(b)). As lamellipodia formation and dissociation of IQGAP1 and kinesin-1 are inhibited by a phosphoinositide 3-kinase (PI3K) inhibitor, the dissociation of IQGAP1 and kinesin-1 from the Rac1CLIP-170 complex is a prerequisite for lamellipodia formation in response to growth factor stimulation; this depends on PI3K that is activated by the activated growth factor receptor (Figure $1(\mathrm{a})$ ).

\section{Membrane Targeting of WAVE2 along Microtubules}

In order to form lamellipodia, WAVE2 needs to be transported to the leading edge of cells prior to lamellipodia formation $[76,77]$. WAVE2 is known to form multiprotein complexes that include Abi-1, Sra-1, Nap-1, and HSPC300 [78-80]. WAVE2 also forms a complex with IQGAP1 and kinesin-1 in growth-arrested breast cancer cells (Figure 1(a)), and the amounts of these proteins relative to WAVE2 increase after stimulation of the cells with growth factor [65] (Figure 1(b)). As IQGAP1 and kinesin-1 dissociate from the Rac1-CLIP-170 complex upon growth factor stimulation, without significant alterations in the total amounts of IQGAP1 and kinesin-1, IQGAP1 and kinesin-1 that are bound to WAVE2 might be proteins that previously dissociated from the complex (Figure 1(b)). In spite of this, additional binding of IQGAP1 and kinesin-1 to WAVE2 appears to be insufficient for WAVE2 translocation to the cell cortex. Many investigations have revealed that a p21activated protein kinase Pak1 [81, 82], which is one of the downstream effectors of Rac1 [81, 83, 84], is constitutively associated with WAVE2 [66] (Figure 2(a)). Pak1 is thought to regulate not only actin reorganization through several reported substrates, including LIM kinase [85], p41-Arc [86], and filamin [87], but also microtubule dynamics through stathmin [88-90], a microtubule destabilizing protein [91, 92]. As direct interaction between Rac1 and Pak1 or WAVE2 is not detected in breast cancer cells, it is reasonable to assume that $\beta$ PIX, the Pak-interacting nucleotide exchange factor of Rac/Cdc42 [93], plays an important role in the signal transduction between Racl and Pak1. $\beta$ PIX is constitutively coupled to GIT1 and recruited to WAVE2bound Pak1 in response to growth factor stimulation [94]. Upon growth factor stimulation, the WAVE2-bound Pak1 is activated and in turn phosphorylates stathmin [66] (Figures 2(a) and 2(b)). The putative phosphorylation sites within stathmin are Ser16, Ser25, Ser38, and Ser63 [95]. Among these, growth factor stimulation causes phosphorylation at Ser25 and Ser38, although phosphorylation at Ser38 alone is dependent on Pak1 in breast cancer cells [66]. This implies that serine/threonine protein kinases other than Pak1 phosphorylate stathmin at Ser25. In either case, the microtubule destabilizing activity of stathmin is inactivated by phosphorylation [88-90], and the phosphorylated stathmin is recruited to kinesin-1; this complexes with WAVE2 and Pak1 and leads to the promotion of microtubule growth [66] (Figure 2(b)). Stathmin binding to kinesin1 was thought to be transient and to play a role in the transportation of tubulin heterodimers to the microtubule ends [95]; however, stathmin binding to kinesin-1 and tubulin heterodimers is maintained after growth factor stimulation [66]. This suggests the presence of a partner protein that facilitates the sustained linking of stathmin to the microtubule ends. The dynamic properties of microtubules are regulated by "plus-end-binding proteins" [9698] that include CLIP, CLIP-associated protein (CLASPs), dynein/dynactin, APC (adenomatous polyposis coli), and EB-family proteins [99-101]. EB1 recognizes specific sites 


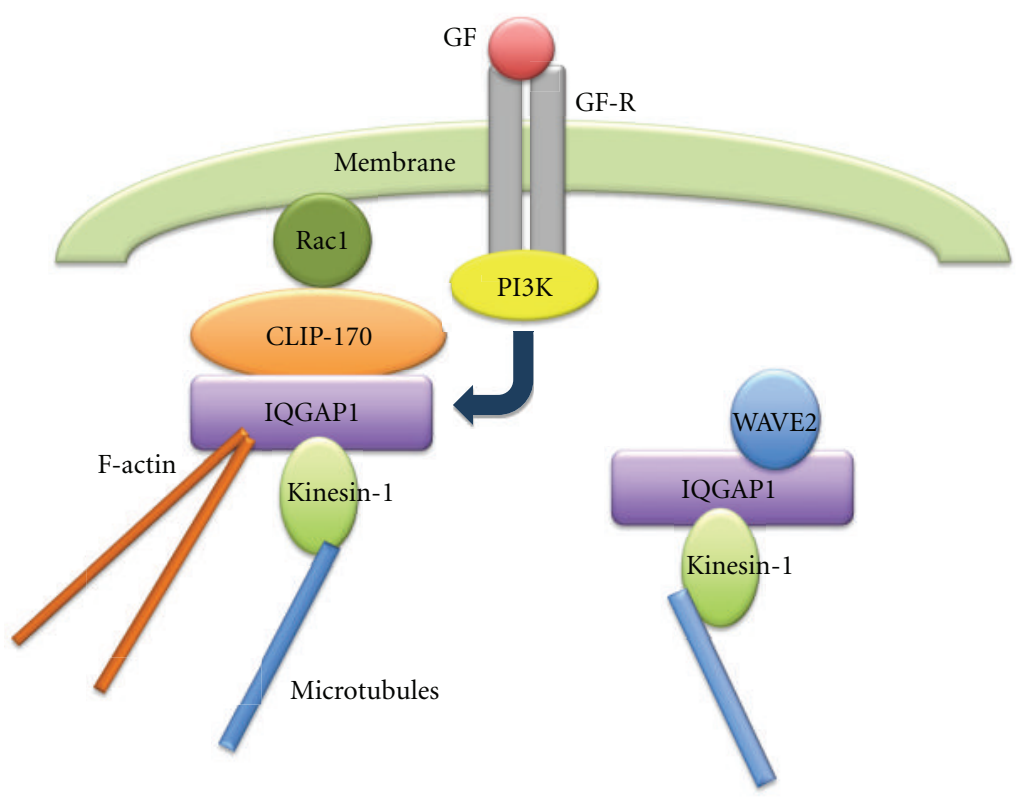

(a)
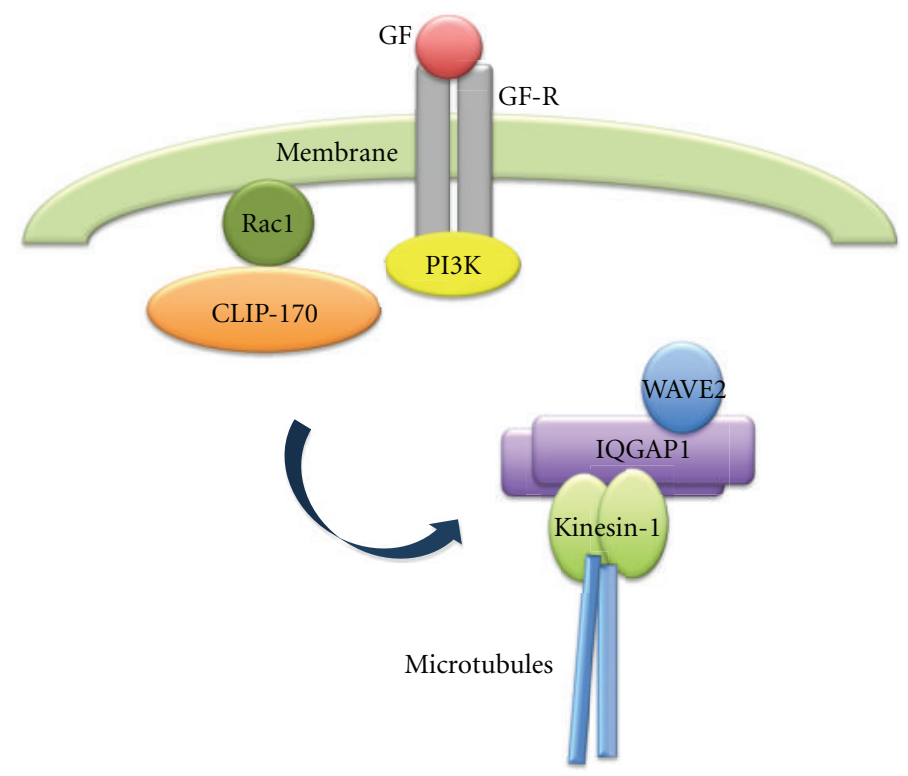

(b)

FIGURE 1: PI3K-dependent dissociation of IQGAP1 and kinesin-1 from the Rac1-CLIP-170 complex and successive binding of them to WAVE2 after GF stimulation. (a) IQGAP1 and kinesin-1, which are bound to Rac1 via CLIP-170 in growth-arrested cells, dissociate from the Rac1-CLIP-170 complex after GF stimulation in a PI3K-dependent manner. (b) Dissociated IQGAP1 and kinesin-1 bind to the WAVE2 complex, which consists of IQGAP1 and kinesin-1. GF: growth factor; GF-R: growth factor receptor; PI3K: phosphoinositide 3-kinase; CLIP-170: cytoplasmic linker protein 170; IQGAP1: IQ motif-containing guanine nucleotide activating protein 1; WAVE2: Wiskott-Aldrich protein verprolin homology protein 2; F-actin: actin filaments.

at the ends of growing microtubules [102] and promotes persistent microtubule growth [103]. Investigation of the stathmin-binding partners revealed that stathmin is constitutively associated with EB1 in the cytoplasm of growtharrested cells [104]. After phosphorylation of stathmin by Pak1, the phosphorylated stathmin-EB1 complex becomes associated, in an EB1-dependent manner, with the ends of microtubules that bear the WAVE2 complex [104]. Depletion of stathmin does not inhibit microtubule growth but inhibits WAVE2 translocation and lamellipodia formation [66], while EB1 depletion does not inhibit microtubule growth but inhibits stathmin binding to kinesin-1 at the microtubule ends, WAVE2 translocation, and lamellipodia formation [104]. Taken together, growth factor-induced 


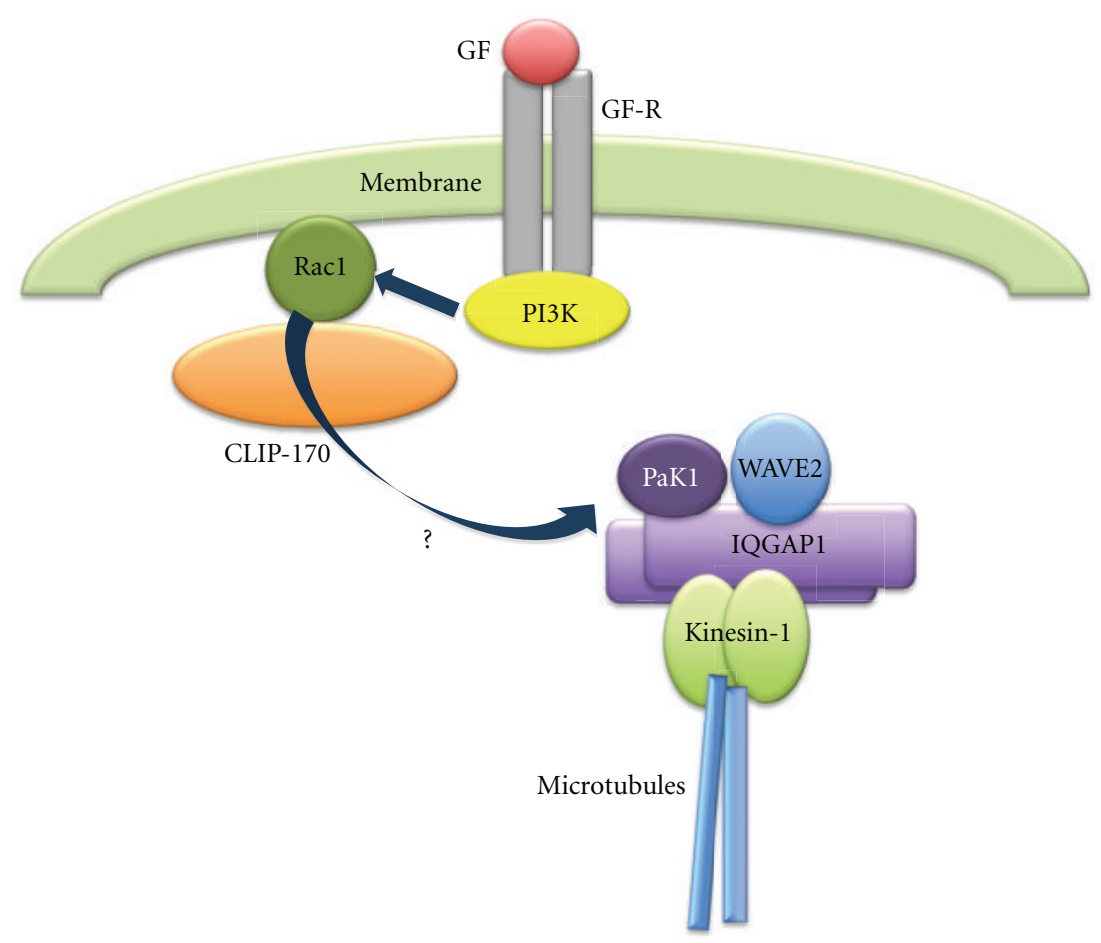

(a)

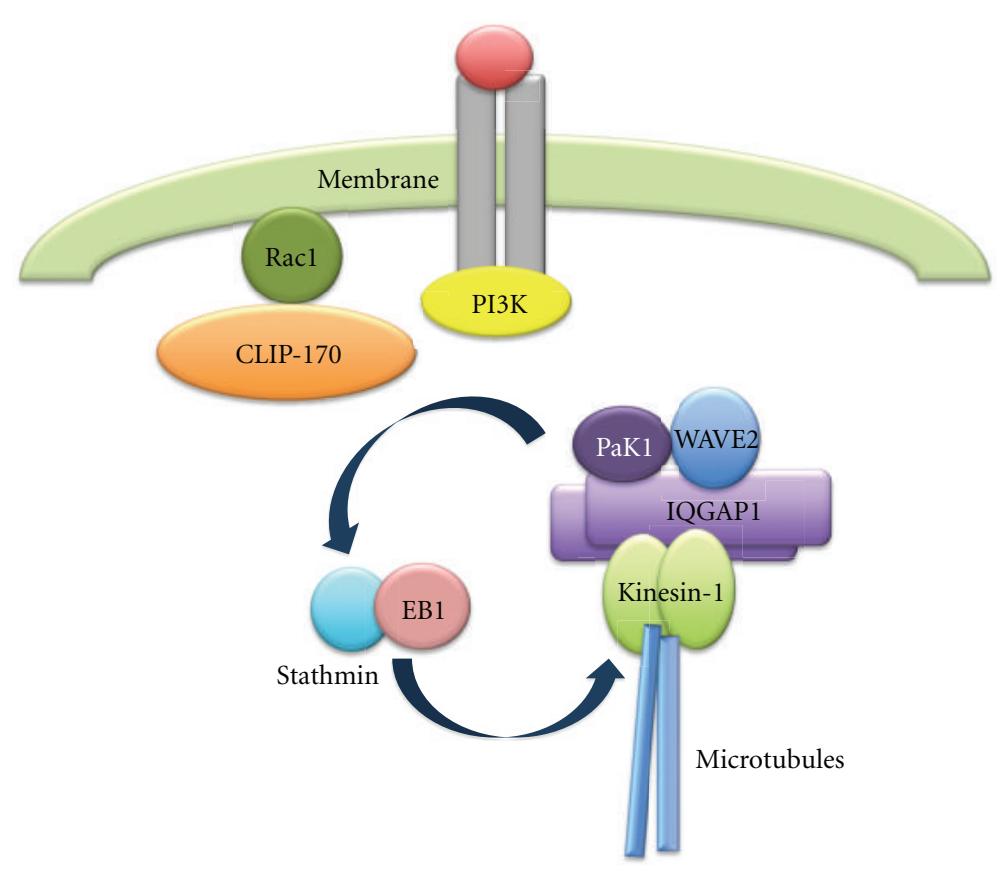

(b)

Figure 2: Activation of WAVE2-bound Pak1, phosphorylation of stathmin by Pak1, and recruitment of the phosphorylated stathmin-EB1 complex to the microtubule ends that bear the WAVE2 complex. (a) WAVE2-bound Pak1 is activated and in turn phosphorylates stathmin that complexes with EB1. (b) The phosphorylated stathmin-EB1 complex is recruited to microtubule ends that bear the WAVE2 complex through kinesin-1. Pak1: p21-activated protein kinase 1; EB1: microtubule end-binding protein 1. 
and Pak1-dependent phosphorylation of stathmin triggers the EB1-mediated specific binding of the phosphorylated stathmin-EB1 complex to the WAVE2-bearing microtubule ends, thereby leading to WAVE2 translocation and lamellipodia formation (Figure 2(b)).

\section{Control of Directional Lamellipodia Formation toward Growth Factor}

The process of cancer cell migration and invasion involves intravasation and extravasation of cells into and out of blood vessels [105]. Therefore, it is highly likely that cancer cell migration and invasion are directionally controlled by extracellular stimuli such as serum growth factors. If this theory is correct, promotion of persistent growth of the WAVE2-bearing microtubules by the binding of the stathmin-EB1 complex seems to be insufficient for the directional membrane anchoring of microtubules, that is, without the aid of partner proteins. For example, the endbinding proteins CLASPs link microtubule ends to the cell cortex by the phosphatidylinosito 3,4,5-triphosphat- ( $\left.\mathrm{PIP}_{3}{ }^{-}\right)$ binding protein LL5 $\beta$ as a partner protein [106]. $\mathrm{PIP}_{3}$, a lipid component of the cytoplasmic membrane produced by $\mathrm{PI} 3 \mathrm{~K}$, is known to be the membrane target of many proteins $[107-111]$ that contain the pleckstrin homology $(\mathrm{PH})$ domain (e.g., PKB/Akt $[112,113]$ ), the basic region (e.g., WASP and WAVE2 $[76,114])$, or the IRSp53/missing-inmetastasis (MIM) domain IMD (e.g., IRSp53 [115, 116]). In lamellipodia-forming breast cancer cells, IRSp53 is constitutively associated with the WAVE2 complex that involves EB1 and plays an indispensable role in anchoring the complex to $\mathrm{PIP}_{3}$ [117]. IRSp53 is a linker protein [118-120] that interacts with the proline-rich region of WAVE2 through its central Src-homology 3 (SH3) domain [118, 121]. Therefore, directional cell migration through lamellipodia formation may be regulated by the interaction between WAVE2-bound IRSp53 as the $\mathrm{PIP}_{3}$-binding partner protein and $\mathrm{PIP}_{3}$ as the membrane target molecule; this suggests that the direction of membrane anchoring of microtubules that bear the WAVE2 complex is determined by the sites where $\mathrm{PIP}_{3}$ is produced. In cells cultured in a chemotaxis chamber, only growth factor receptor in the membrane region facing high concentrations of growth factor was activated [104]. Local activation of the receptor causes recruitment of PI3K that in turn produces $\mathrm{PIP}_{3}$ in close proximity to the activated receptor [104] (Figure 3(a)), thereby leading to local interaction between IRSp53-bound WAVE2 and $\mathrm{PIP}_{3}$, and thus the directional formation of lamellipodia towards the growth factor source (Figure 3(b)).

In the context of $\mathrm{PIP}_{3}$-binding proteins for lamellipodia formation, nonmuscle myosin IIA heavy chain MYH9 [122124] has the ability to bind to both $\mathrm{PIP}_{3}$ and WAVE2 [125]. Whereas MYH9 binding to WAVE2 is constitutive and requires the motor activity of myosin II, MYH9 binding to $\mathrm{PIP}_{3}$ is induced only after WAVE2 membrane targeting by growth factor activation [125]. The binding of MYH9 to WAVE2 is probably through the interaction between the SH3-like domain of MYH9 and the proline-rich domain of WAVE2; however, MYH9 lacks a $\mathrm{PH}$ domain, unlike myosin $1 \mathrm{~b}$ and myosin $\mathrm{X}$, which bind to $\mathrm{PIP}_{3}$ through their PH domains [126, 127]. Nevertheless, both MYH9 and the motor activity of nonmuscle myosin II are crucial for lamellipodia formation, as they induce convex F-actin arcs at the leading edge of cells [125] (Figure 4). Nonmuscle cells express multiple myosin II proteins, including myosin IIA, myosin IIB, and myosin IIC [122-124]; these are implicated in regulating many cellular processes, including cell spreading, migration, and cytokinesis [128-131], through generating the intracellular contractile forces and tension as conventional motor proteins by associating with F-actin. Thus, myosin IIA might also play a crucial role in cell migration through lamellipodia formation by providing the contractile forces and tension for the F-actin network initially rearranged by WAVE2, IRSp53, and PIP 3 through the variable turnover dynamics of F-actin $[132,133]$ to form a convex arc at the leading edge of cells (Figure 4). As IRSp53 exhibits F-actin-bundling activity [134, 135], the formation of a lining of F-actin at the leading edge of cells might be mediated by nonmuscle myosin IIA in cooperation with IRSp53.

Among the proteins and molecules that are involved in regulation of lamellipodia formation, WAVE2, N-WASP, PI3K, Rac1, stathmin, and microtubules are also necessary for cell invasion [69, 136-139]. Because cell invasion is accomplished by intensive accumulation of the F-actin bundles at the tips of cell protrusions where cells invade through the basement membrane matrix and narrow gaps [138], the signaling and regulatory molecules leading to cell invasion may share many common molecules, leading to cell migration through lamellipodia formation.

\section{Conclusion}

Cell migration and invasion are believed to require the formation of lamellipodia at the leading edge of cells by rearrangement of F-actin. Lamellipodia formation is preceded by membrane targeting of WAVE2 along microtubules. WAVE2 forms multiprotein complexes consisting of IQGAP1, kinesin-1, Pak1, IRSp53, and nonmuscle myosin IIA. Membrane targeting of the WAVE2 complex is triggered by binding of IQGAP1 and kinesin-1, which are dissociated from the Rac1-CLIP-170 complex upon PI3K activation by the activated growth factor receptor. Concomitantly, WAVE2-bound Pak1 after Rac1-dependent activation phosphorylates stathmin, followed by binding of the stathminEB1 complex to the microtubule ends that bear the WAVE2 complex; this results in the promotion of persistent microtubule growth towards the cell cortex. The WAVE2 complex that targets the cell membrane is anchored by WAVE2bound IRSp53 and nonmuscle myosin IIA to $\mathrm{PIP}_{3}$; $\mathrm{PIP}_{3}$ is produced by PI3K near the growth factor receptor that is locally activated in the membrane region facing higher concentrations of growth factor. Colocalization of WAVE2, IRSp53, nonmuscle myosin IIA, and $\mathrm{PIP}_{3}$ induces the directional formation of a convex F-actin arc lamellipodium. The discovery of many essential signaling and regulatory 


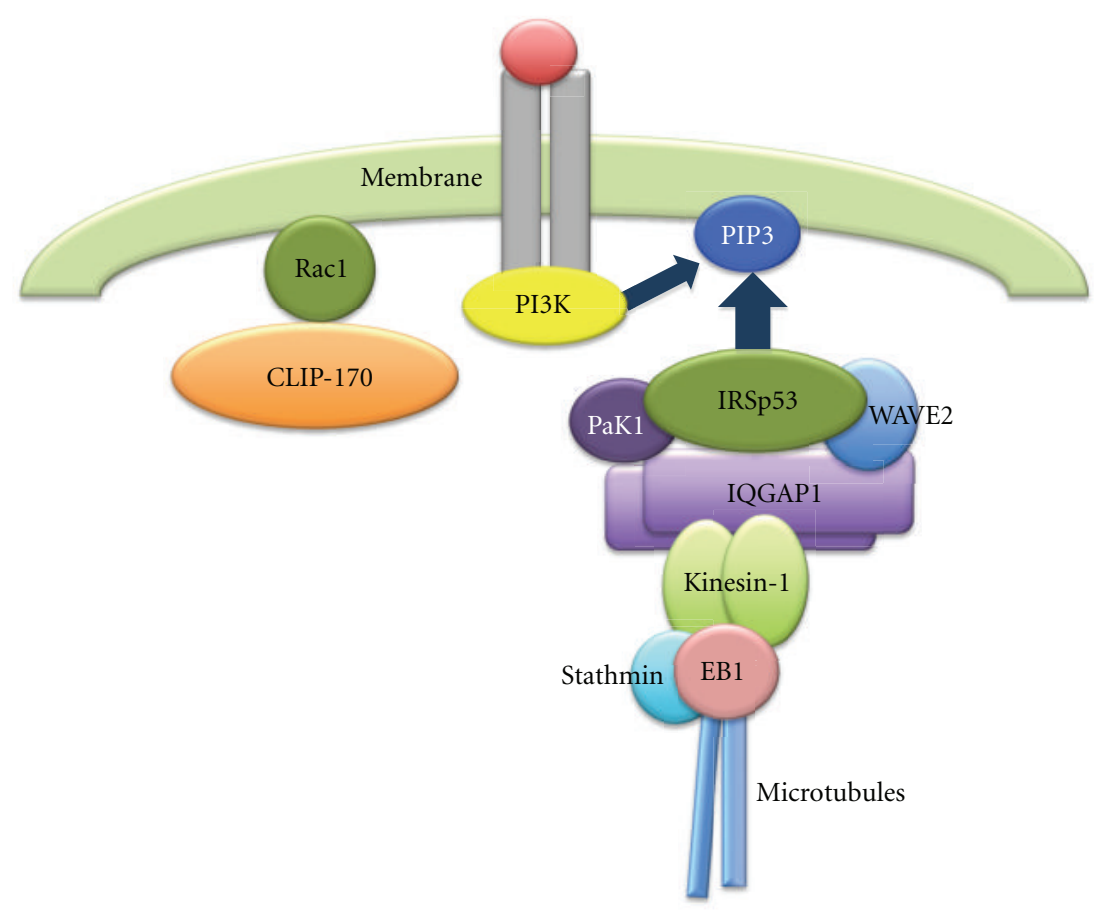

(a)

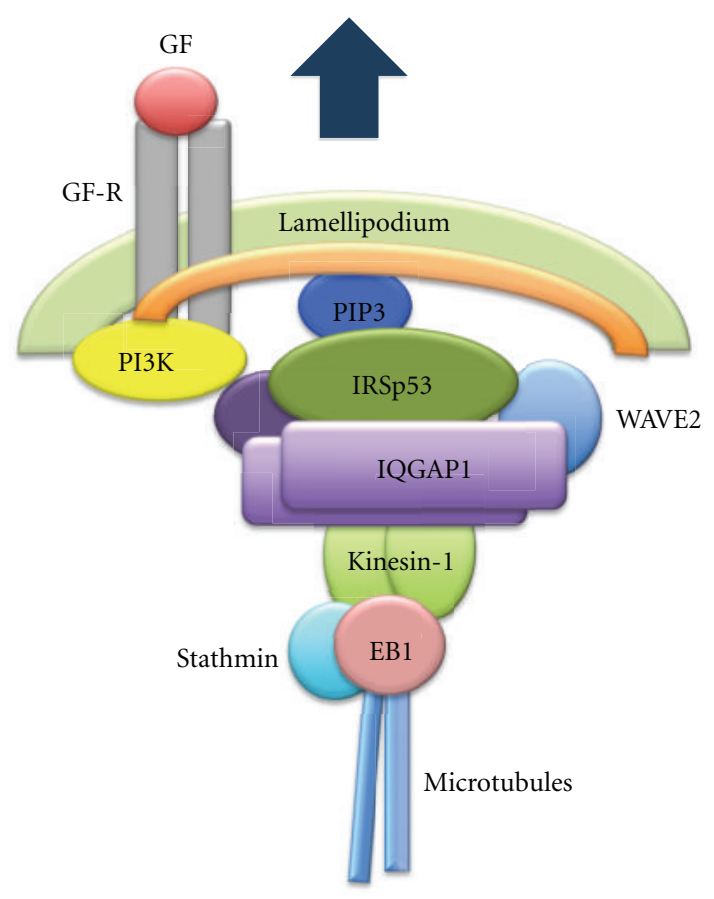

(b)

FIGURE 3: Directional membrane targeting and anchoring of WAVE2 to PIP 3 by IRSp53, leading to the directional formation of lamellipodia toward GF. (a) Promotion of microtubule growth through recruitment of the stathmin-EB1 complex to the microtubule ends induces membrane targeting of the WAVE2 complex along microtubules. The WAVE2 complex targets the cell cortex and is anchored by IRSp53. IRSp53 links WAVE2 to $\mathrm{PIP}_{3}$ produced by PI3K near GF-R locally activated in the membrane region facing GF. (b) Colocalization of WAVE2, IRSp53, and $\mathrm{PIP}_{3}$ results in the directional formation of lamellipodia towards high concentrations of GF. IRSp53: insulin receptor substrate p53; $\mathrm{PIP}_{3}$ : phosphoinositide 3,4,5-triphosphate. 

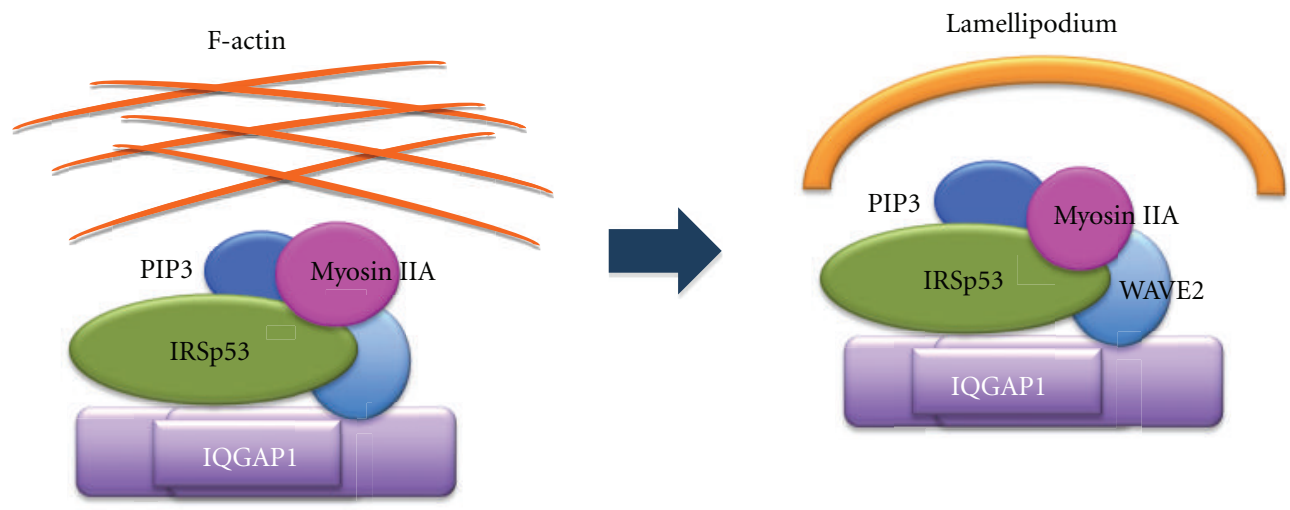

FIGURE 4: The role of nonmuscle myosin IIA in lamellipodia formation. The network of F-actin, initially rearranged by WAVE2, IRSp53, and $\mathrm{PIP}_{3}$, is assembled into lamellipodium, a convex arc of F-actin, by the WAVE2-bound nonmuscle myosin IIA heavy chain MYH9 and the motor activity of nonmuscle myosin II.

molecules for cell migration might have important implications for the development of effective therapeutic agents against cancer cell migration and invasion.

\section{Acknowledgments}

The author is grateful to Katsuo Suzuki for technical assistance and to Tetsuo Ono for persistent encouragement throughout the work.

\section{References}

[1] B. Gumbiner, B. Stevenson, and A. Grimaldi, "The role of the cell adhesion molecule uvomorulin in the formation and maintenance of the epithelial junctional complex," Journal of Cell Biology, vol. 107, no. 4, pp. 1575-1587, 1988.

[2] M. Takeichi, "The cadherins: cell—cell adhesion molecules controlling animal morphogenesis," Development, vol. 102, no. 4, pp. 639-655, 1988.

[3] M. Takeichi, "Cadherin cell adhesion receptors as a morphogenetic regulator," Science, vol. 251, no. 5000, pp. 1451-1455, 1991.

[4] L. Shapiro, A. M. Fannon, P. D. Kwong et al., "Structural basis of cell—cell adhesion by cadherins," Nature, vol. 374, no. 6520, pp. 327-337, 1995.

[5] M. Ozawa, H. Barbault, and R. Kemler, "The cytoplasmic domain of the cell adhesion molecule uvomorulin assoicates with three independent proteins structurally related in different species," EMBO Journal, vol. 8, no. 6, pp. 17111717, 1989.

[6] A. I. Magee and R. S. Buxton, "Transmembrane molecular assemblies regulated by the greater cadherin family," Current Opinion in Cell Biology, vol. 3, no. 5, pp. 854-861, 1991.

[7] S. Hirano, N. Kimoto, Y. Shimoyama, S. Hirohashi, and M. Takeichi, "Identification of a neural $\alpha$-catenin as a key regulator of cadherin function and multicellular organization," Cell, vol. 70, no. 2, pp. 293-301, 1992.

[8] A. Nagafuchi and M. Takeichi, "Cell binding function of Ecadherin is regulated by the cytoplasmic domain," EMBO Journal, vol. 7, no. 12, pp. 3679-3684, 1988.

[9] K. A. Knudsen, A. P. Soler, K. R. Johnson, and M. J. Wheelock, "Interaction of $\alpha$-actinin with the cadherin/catenin cell—cell adhesion complex via $\alpha$-catenin," Journal of Cell Biology, vol. 130, no. 1, pp. 67-77, 1995.

[10] G. Berx, A. M. Cleton-Jansen, F. Nollet et al., "E-cadherin is a tumour/invasion suppressor gene mutated in human lobular breast cancers," EMBO Journal, vol. 14, no. 24, pp. 61076115, 1995.

[11] T. Kadowaki, H. Shiozaki, M. Inoue et al., "E-cadherin and $\alpha$-catenin expression in human esophageal cancer," Cancer Research, vol. 54, no. 1, pp. 291-296, 1994.

[12] J. H. Schipper, U. H. Frixen, J. Behrens, A. Unger, K. Jahnke, and W. Birchmeier, "E-cadherin expression in squamous cell carcinomas of head and neck: inverse correlation with tumor dedifferentiation and lymph node metastasis," Cancer Research, vol. 51, no. 23, pp. 6328-6337, 1991.

[13] Y. Shimoyama and S. Hirohashi, "Expression of E- and Pcadherin in gastric carcinomas," Cancer Research, vol. 51, no. 8, pp. 2185-2192, 1991.

[14] R. A. Morton, C. M. Ewing, A. Nagafuchi, S. Tsukita, and W. B. Isaacs, "Reduction of E-cadherin levels and deletion of the $\alpha$-catenin gene in human prostate cancer cells," Cancer Research, vol. 53, no. 15, pp. 3585-3590, 1993.

[15] Y. Shimoyama, A. Nagafuchi, S. Fujita et al., "Cadherin dysfunction in a human cancer cell line: possible involvement of loss of $\alpha$-catenin expression in reduced cell-cell adhesiveness," Cancer Research, vol. 52, no. 20, pp. 5770-5774, 1992.

[16] W. E. Pierceall, A. S. Woodard, J. S. Morrow, D. Rimm, and E. R. Fearon, "Frequent alterations in E-cadherin and $\alpha$ and $\beta$-catenin expression in human breast cancer cell lines," Oncogene, vol. 11, no. 7, pp. 1319-1326, 1995.

[17] K. Fujii, F. Furukawa, and N. Matsuyoshi, "Ligand activation of overexpressed epidermal growth factor receptor results in colony dissociation and disturbed E-cadherin function in HSC-1 human cutaneous squamous carcinoma cells," Experimental Cell Research, vol. 223, no. 1, pp. 50-62, 1996.

[18] H. Hoschuetzky, H. Aberle, and R. Kemler, " $\beta$-Catenin mediates the interaction of the cadherin-catenin complex with epidermal growth factor receptor," Journal of Cell Biology, vol. 127, no. 5, pp. 1375-1380, 1994.

[19] S. Shibamoto, M. Hayakawa, K. Takeuchi et al., "Tyrosine phosphorylation of $\beta$-catenin and plakoglobin enhanced by hepatocyte growth factor and epidermal growth factor in human carcinoma cells," Cell Adhesion and Communication, vol. 1, no. 4, pp. 295-305, 1994. 
[20] K. Takahashi and K. Suzuki, "Density-dependent inhibition of growth involves prevention of EGF receptor activation by E-cadherin-mediated cell—cell adhesion," Experimental Cell Research, vol. 226, no. 1, pp. 214-222, 1996.

[21] J. Behrens, L. Vakaet, R. Friis et al., "Loss of epithelial differentiation and gain of invasiveness correlates with tyrosine phosphorylation of the E-cadherin/ $\beta$-catenin complex in cells transformed with a temperature-sensitive v-SRC gene," Journal of Cell Biology, vol. 120, no. 3, pp. 757-766, 1993.

[22] M. Hamaguchi, N. Matsuyoshi, Y. Ohnishi, B. Gotoh, M. Takeichi, and Y. Nagai, "P60(v-src) causes tyrosine phosphorylation and inactivation of the N-cadherin-catenin cell adhesion system," EMBO Journal, vol. 12, no. 1, pp. 307-314, 1993.

[23] K. Takahashi, K. Suzuki, and Y. Tsukatani, "Induction of tyrosine phosphorylation and association of $\beta$-catenin with EGF receptor upon tryptic digestion of quiescent cells at confluence," Oncogene, vol. 15, no. 1, pp. 71-78, 1997.

[24] Y. Tsukatani, K. Suzuki, and K. Takahashi, "Loss of densitydependent growth inhibition and dissociation of $\alpha$-Catenin from E-cadherin," Journal of Cellular Physiology, vol. 173, no. 1, pp. 54-63, 1997.

[25] M. F. Gebbink, G. C. Zondag, G. M. Koningstein, E. Feiken, R. W. Wubbolts, and W. H. Moolenaar, "Cell surface expression of receptor protein tyrosine phosphatase RPTP $\mu$ is regulated by cell-cell contact," Journal of Cell Biology, vol. 131, no. 1, pp. 251-260, 1995.

[26] A. Ostman, Q. Yang, and N. K. Tonks, "Expression of DEP1 , a receptor-like protein-tyrosine-phosphatase, is enhanced with increasing cell density," Proceedings of the National Academy of Sciences of the United States of America, vol. 91, no. 21, pp. 9680-9684, 1994.

[27] J. Balsamo, C. Arregui, T. Leung, and J. Lilien, "The nonreceptor protein tyrosine phosphatase PTP1B binds to the cytoplasmic domain of $\mathrm{N}$-cadherin and regulates the cadherin-actin linkage," Journal of Cell Biology, vol. 143, no. 2, pp. 523-532, 1998.

[28] J. Balsamo, T. Leung, H. Ernst, M. K. Zanin, S. Hoffman, and J. Lilien, "Regulated binding of a PTP1B-like phosphatase to N-cadherin: control of cadherin-mediated adhesion by dephosphorylation of $\beta$-catenin," Journal of Cell Biology, vol. 134, no. 3, pp. 801-813, 1996.

[29] S. M. Brady-Kalnay, T. Mourton, J. P. Nixon et al., "Dynamic interactions of $\mathrm{PTP} \mu$ with multiple cadherins in vivo," Journal of Cell Biology, vol. 141, no. 1, pp. 287-296, 1998.

[30] S. M. Brady-Kalnay, D. L. Rimm, and N. K. Tonks, "Receptor protein tyrosine phosphatase $\mathrm{PTP} \mu$ associates with cadherins and catenins in vivo," Journal of Cell Biology, vol. 130, no. 4, pp. 977-986, 1995.

[31] R. M. Kypta, H. Su, and L. F. Reichardt, "Association between a transmembrane protein tyrosine phosphatase and the cadherin—catenin complex," Journal of Cell Biology, vol. 134, no. 6, pp. 1519-1529, 1996.

[32] L. Weissbach, J. Settleman, M. F. Kalady et al., "Identification of a human RasGAP-related protein containing calmodulinbinding motifs," Journal of Biological Chemistry, vol. 269, no. 32, pp. 20517-20521, 1994.

[33] A. M. Bashour, A. T. Fullerton, M. J. Hart, and G. S. Bloom, "IQGAP1, a Rac- and Cdc42-binding protein, directly binds and cross- links microfilaments," Journal of Cell Biology, vol. 137, no. 7, pp. 1555-1566, 1997.

[34] M. Fukataf, S. Kuroda, K. Fujii et al., "Regulation of crosslinking of actin filament by IQGAP1, a target for Cdc42,"
Journal of Biological Chemistry, vol. 272, no. 47, pp. 2957929583, 1997.

[35] M. D. Brown and D. B. Sacks, "IQGAP1 in cellular signaling: bridging the GAP," Trends in Cell Biology, vol. 16, no. 5, pp. 242-249, 2006.

[36] G. Izumi, T. Sakisaka, T. Baba, S. Tanaka, K. Morimoto, and Y. Takai, "Endocytosis of E-cadherin regulated by Rac and Cdc42 small G proteins through IQGAP1 and actin filaments," Journal of Cell Biology, vol. 166, no. 2, pp. 237248, 2004.

[37] K. Takahashi, E. Nakajima, and K. Suzuki, "Involvement of protein phosphatase $2 \mathrm{~A}$ in the maintenance of $\mathrm{E}$ cadherin-mediated cell—cell adhesion through recruitment of IQGAP1," Journal of Cellular Physiology, vol. 206, no. 3, pp. 814-820, 2006.

[38] K. Suzuki and K. Takahashi, "Induction of E-cadherin endocytosis by loss of protein phosphatase 2A expression in human breast cancers," Biochemical and Biophysical Research Communications, vol. 349, no. 1, pp. 255-260, 2006.

[39] G. A. Calin, M. G. di Iasio, E. Caprini et al., "Low frequency of alterations of the $\alpha$ (PPP2R1A) and $\beta$ (PPP2R1B) isoforms of the subunit $\mathrm{A}$ of the serine-threonine phosphatase $2 \mathrm{~A}$ in human neoplasms," Oncogene, vol. 19, no. 9, pp. 1191-1195, 2000.

[40] R. Ruediger, H. T. Pham, and G. Walter, "Alterations in protein phosphatase $2 \mathrm{~A}$ subunit interaction in human carcinomas of the lung and colon with mutations in the A $\beta$ subunit gene," Oncogene, vol. 20, no. 15, pp. 1892-1899, 2001.

[41] S. S. Wang, E. D. Esplin, J. L. Li et al., "Alterations of the PPP2R1B gene in human lung and colon cancer," Science, vol. 282, no. 5387, pp. 284-287, 1998.

[42] V. Nunbhakdi-Craig, T. Machleidt, E. Ogris, D. Bellotto, C. L. White III, and E. Sontag, "Protein phosphatase 2A associates with and regulates atypical $\mathrm{PKC}$ and the epithelial tight junction complex," Journal of Cell Biology, vol. 158, no. 5, pp. 967-978, 2002.

[43] J. Mulrooney, K. Foley, S. Vineberg, M. Barreuther, and L. Grabel, "Phosphorylation of the $\beta 1$ integrin cytoplasmic domain: toward an understanding of function and mechanism," Experimental Cell Research, vol. 258, no. 2, pp. 332$341,2000$.

[44] K. Suzuki and K. Takahashi, "Reduced cell adhesion during mitosis by threonine phosphorylation of $\beta 1$ integrin," Journal of Cellular Physiology, vol. 197, no. 2, pp. 297-305, 2003.

[45] K. Suzuki and K. Takahashi, "Reduced expression of the regulatory A subunit of serine/threonine protein phosphatase $2 \mathrm{~A}$ in human breast cancer MCF-7 cells," International Journal of Oncology, vol. 23, no. 5, pp. 1263-1268, 2003.

[46] K. Suzuki, Y. Chikamatsu, and K. Takahashi, "Requirement of protein phosphatase 2A for recruitment of IQGAP1 to Racbound $\beta 1$ integrin," Journal of Cellular Physiology, vol. 203, no. 3, pp. 487-492, 2005.

[47] E. Nakajima, K. Suzuki, and K. Takahashi, "Mitotic dissociation of IQGAP1 from Rac-bound $\beta 1$-integrin is mediated by protein phosphatase 2A," Biochemical and Biophysical Research Communications, vol. 326, no. 1, pp. 249-253, 2004.

[48] K. Takahashi and K. Suzuki, "Regulation of protein phosphatase 2A-mediated recruitment of IQGAP1 to $\beta 1$ integrin by EGF through activation of $\mathrm{Ca}^{2+} /$ calmodulin- dependent protein kinase II," Journal of Cellular Physiology, vol. 208, no. 1, pp. 213-219, 2006.

[49] T. Kamei, T. Matozaki, T. Sakisaka et al., "Coendocytosis of cadherin and c-Met coupled to disruption of cell-cell 
adhesion in MDCK cells-regulation by Rho, Rac and Rab small G proteins," Oncogene, vol. 18, no. 48, pp. 6776-6784, 1999.

[50] Y. Fujita, G. Krause, M. Scheffner et al., "Hakai, a c-Cbllike protein, ubiquitinates and induces endocytosis of the Ecadherin complex," Nature Cell Biology, vol. 4, no. 3, pp. 222231, 2002.

[51] T. L. Le, A. S. Yap, and J. L. Stow, "Recycling of E-cadherin: a potential mechanism for regulating cadherin dynamics," Journal of Cell Biology, vol. 146, no. 1, pp. 219-232, 1999.

[52] F. Palacios, J. K. Schweitzer, R. L. Boshans, and C. D'Souza-Schorey, “ARF6-GTP recruits Nm23-H1 to facilitate dynamin-mediated endocytosis during adherens junctions disassembly," Nature Cell Biology, vol. 4, no. 12, pp. 929-936, 2002.

[53] T. J. Mitchison and L. P. Cramer, "Actin-based cell motility and cell locomotion," Cell, vol. 84, no. 3, pp. 371-379, 1996.

[54] T. M. Svitkina and G. G. Borisy, "Arp2/3 complex and actin depolymerizing factor/cofilin in dendritic organization and treadmilling of actin filament array in lamellipodia," Journal of Cell Biology, vol. 145, no. 5, pp. 1009-1026, 1999.

[55] L. M. Machesky, R. D. Mullins, H. N. Higgs et al., "Scar, a WASp-related protein, activates nucleation of actin filaments by the Arp2/3 complex," Proceedings of the National Academy of Sciences of the United States of America, vol. 96, no. 7, pp. 3739-3744, 1999.

[56] T. D. Pollard and G. G. Borisy, "Cellular motility driven by assembly and disassembly of actin filaments," Cell, vol. 112, no. 4, pp. 453-465, 2003.

[57] A. Hall, "Rho GTpases and the actin cytoskeleton," Science, vol. 279, no. 5350, pp. 509-514, 1998.

[58] J. M. Derry, H. D. Ochs, and U. Francke, "Isolation of a novel gene mutated in Wiskott-Aldrich syndrome," Cell, vol. 78, no. 4, pp. 635-644, 1994.

[59] H. N. Higgs and T. D. Pollard, "Activation by Cdc42 and PIP2 of Wiskott-Aldrich Syndrome protein (WASp) stimulates actin nucleation by Arp2/3 complex," Journal of Cell Biology, vol. 150, no. 6, pp. 1311-1320, 2000.

[60] H. Miki, K. Miura, and T. Takenawa, "N-WASP, a novel actindepolymerizing protein, regulates the cortical cytoskeletal rearrangement in a PIP2-dependent manner downstream of tyrosine kinases," EMBO Journal, vol. 15, no. 19, pp. 5326 5335, 1996.

[61] S. Suetsugu, H. Miki, and T. Takenawa, "Identification of two human WAVE/SCAR homologues as general actin regulatory molecules which associate with the Arp2/3 complex," Biochemical and Biophysical Research Communications, vol. 260, no. 1, pp. 296-302, 1999.

[62] T. Takenawa and S. Suetsugu, "The WASP-WAVE protein network: connecting the membrane to the cytoskeleton," Nature Reviews Molecular Cell Biology, vol. 8, no. 1, pp. 3748, 2007.

[63] M. Lorenz, H. Yamaguchi, Y. Wang, R. H. Singer, and J. Condeelis, "Imaging sites of N-WASP activity in lamellipodia and invadopodia of carcinoma cells," Current Biology, vol. 14, no. 8, pp. 697-703, 2004.

[64] T. Takenawa and H. Miki, "WASP and WAVE family proteins: key molecules for rapid rearrangement of cortical actin filaments and cell movement," Journal of Cell Science, vol. 114 , no. 10, pp. 1801-1809, 2001.

[65] K. Takahashi and K. Suzuki, "Requirement of kinesinmediated membrane transport of WAVE2 along microtubules for lamellipodia formation promoted by hepatocyte growth factor," Experimental Cell Research, vol. 314, no. 1112, pp. 2313-2322, 2008.

[66] K. Takahashi and K. Suzuki, "Membrane transport of WAVE2 and lamellipodia formation require Pak1 that mediates phosphorylation and recruitment of stathmin/Op18 to Pak1WAVE2-kinesin complex," Cellular Signalling, vol. 21, no. 5, pp. 695-703, 2009.

[67] H. Nakagawa, H. Miki, M. Nozumi et al., "IRSp53 is colocalised with WAVE2 at the tips of protruding lamellipodia and filopodia independently of Mena," Journal of Cell Science, vol. 116, no. 12, pp. 2577-2583, 2003.

[68] H. Miki, S. Suetsugu, and T. Takenawa, "WAVE, a novel WASP-family protein involved in actin reorganization induced by Rac," EMBO Journal, vol. 17, no. 23, pp. 69326941, 1998

[69] S. Kurisu, S. Suetsugu, D. Yamazaki, H. Yamaguchi, and T. Takenawa, "Rac-WAVE2 signaling is involved in the invasive and metastatic phenotypes of murine melanoma cells," Oncogene, vol. 24, no. 8, pp. 1309-1319, 2005.

[70] P. Pierre, J. Scheel, J. E. Rickard, and T. E. Kreis, "CLIP-170 links endocytic vesicles to microtubules," Cell, vol. 70, no. 6, pp. 887-900, 1992.

[71] F. Perez, G. S. Diamantopoulos, R. Stalder, and T. E. Kreis, "CLIP-170 highlights growing microtubule ends in vivo," Cell, vol. 96, no. 4, pp. 517-527, 1999.

[72] N. Hirokawa, K. K. Pfister, H. Yorifuji, M. C. Wagner, S. T. Brady, and G. S. Bloom, "Submolecular domains of bovine brain kinesin identified by electron microscopy and monoclonal antibody decoration," Cell, vol. 56, no. 5, pp. 867-878, 1989.

[73] K. K. Pfister, M. C. Wagner, D. L. Stenoien, S. T. Brady, and G. S. Bloom, "Monoclonal antibodies to kinesin heavy and light chains stain vesicle-like structures, but not microtubules, in cultured cells," Journal of Cell Biology, vol. 108, no. 4, pp. 1453-1463, 1989.

[74] K. Suzuki and K. Takahashi, "Regulation of lamellipodia formation and cell invasion by CLIP-170 in invasive human breast cancer cells," Biochemical and Biophysical Research Communications, vol. 368, no. 2, pp. 199-204, 2008.

[75] M. Fukata, T. Watanabe, J. Noritake et al., "Rac1 and Cdc42 capture microtubules through IQGAP1 and CLIP-170," Cell, vol. 109, no. 7, pp. 873-885, 2002.

[76] T. Oikawa, H. Yamaguchi, T. Itoh et al., "Ptdlns $(3,4,5) \mathrm{P}_{3}$ binding is necessary for WAVE2-induced formation of lamellipodia," Nature Cell Biology, vol. 6, no. 5, pp. 420-426, 2004.

[77] Y. Leng, J. Zhang, K. Badour et al., "Abelson-interactor1 promotes WAVE2 membrane translocation and Abelsonmediated tyrosine phosphory lation required for WAVE2 activation," Proceedings of the National Academy of Sciences of the United States of America, vol. 102, no. 4, pp. 1098-1103, 2005.

[78] M. Innocenti, E. Frittoli, I. Ponzanelli et al., "Phosphoinositide 3-kinase activates Rac by entering in a complex with Eps8, Abi1, and Sos-1," Journal of Cell Biology, vol. 160, no. 1, pp. 17-23, 2003.

[79] P. Kunda, G. Craig, V. Dominguez, and B. Baum, "Abi, Sra1, and kette control the stability and localization of SCAR/WAVE to regulate the formation of actin-based protrusions," Current Biology, vol. 13, no. 21, pp. 1867-1875, 2003.

[80] A. Steffen, K. Rottner, J. Ehinger et al., "Sra-1 and Nap1 link Rac to actin assembly driving lamellipodia formation," EMBO Journal, vol. 23, no. 4, pp. 749-759, 2004. 
[81] G. M. Bokoch, "Biology of the p21-activated kinases," Annual Review of Biochemistry, vol. 72, pp. 743-781, 2003.

[82] R. Kumar, A. E. Gururaj, and C. J. Barnes, "p21-activated kinases in cancer," Nature Reviews Cancer, vol. 6, no. 6, pp. 459-471, 2006.

[83] S. Bagrodia, S. J. Taylor, K. A. Jordon, L. van Aelst, and R. A. Cerione, "A novel regulator of p21-activated kinases," Journal of Biological Chemistry, vol. 273, no. 37, pp. 23633-23636, 1998.

[84] R. H. Daniels, P. S. Hall, and G. M. Bokoch, "Membrane targeting of p21-activated kinase 1 (PAK1) induces neurite outgrowth from PC12 cells," EMBO Journal, vol. 17, no. 3, pp. 754-764, 1998.

[85] M. Davila, A. R. Frost, W. E. Grizzle, and R. Chakrabarti, "LIM kinase 1 is essential for the invasive growth of prostate epithelial cells: implications in prostate cancer," Journal of Biological Chemistry, vol. 278, no. 38, pp. 36868-36875, 2003.

[86] R. K. Vadlamudi, F. Li, C. J. Barnes, R. Bagheri-Yarmand, and R. Kumar, "p-41-Arc subunit of human Arp2/3 complex is a p21-activated kinase-1-interacting substrate," EMBO Reports, vol. 5, no. 2, pp. 154-160, 2004.

[87] R. K. Vadlamudi, F. Li, L. Adam et al., "Filamin is essential in actin cytoskeletal assembly mediated by $\mathrm{p} 21$-activated kinase 1," Nature Cell Biology, vol. 4, no. 9, pp. 681-690, 2002.

[88] S. B. Horwitz, H. J. Shen, L. He et al., "The microtubuledestabilizing activity of metablastin (p19) is controlled by phosphorylation," Journal of Biological Chemistry, vol. 272, no. 13, pp. 8129-8132, 1997.

[89] H. Daub, K. Gevaert, J. Vandekerckhove, A. Sobel, and A. Hall, "Rac/Cdc42 and p65PAK regulate the microtubuledestabilizing protein stathmin through phosphorylation at serine 16," Journal of Biological Chemistry, vol. 276, no. 3, pp. 1677-1680, 2001.

[90] T. Wittmann, G. M. Bokoch, and C. M. WatermanStorer, "Regulation of microtubule destabilizing activity of Op18/Stathmin downstream of Rac1," Journal of Biological Chemistry, vol. 279, no. 7, pp. 6196-6203, 2004.

[91] L. D. Belmont and T. J. Mitchison, "Identification of a protein that interacts with tubulin dimers and increases the catastrophe rate of microtubules," Cell, vol. 84, no. 4, pp. 623-631, 1996.

[92] L. Cassimeris, "The oncoprotein 18/stathmin family of microtubule destabilizers," Current Opinion in Cell Biology, vol. 14, no. 1, pp. 18-24, 2002.

[93] E. Manser, T. H. Loo, C. G. Koh et al., "PAK kinases are directly coupled to the PIX family of nucleotide exchange factors," Molecular Cell, vol. 1, no. 2, pp. 183-192, 1998.

[94] S. Morimura, K. Suzuki, and K. Takahashi, " $\beta$ PIX and GIT1 regulate HGF-induced lamellipodia formation and WAVE2 transport," Biochemical and Biophysical Research Communications, vol. 382, no. 3, pp. 614-619, 2009.

[95] L. Jourdain, P. Curmi, A. Sobel, D. Pantaloni, and M. F. Carlier, "Stathmin: a tubulin-sequestering protein which forms a ternary T2S complex with two tubulin molecules," Biochemistry, vol. 36, no. 36, pp. 10817-10821, 1997.

[96] S. C. Schuyler and D. Pellman, "Microtubule "plus-endtracking proteins": the end is just the beginning," Cell, vol. 105, no. 4, pp. 421-424, 2001.

[97] N. Galjart and F. Perez, "A plus-end raft to control microtubule dynamics and function," Current Opinion in Cell Biology, vol. 15, no. 1, pp. 48-53, 2002.

[98] N. Galjart, "CLIPs and CLASPs and cellular dynamics," Nature Reviews Molecular Cell Biology, vol. 6, no. 6, pp. 487498, 2005.
[99] J. Howard and A. A. Hyman, "Dynamics and mechanics of the microtubule plus end," Nature, vol. 422, no. 6933, pp. 753-758, 2003.

[100] Y. Mimori-Kiyosue and S. Tsukita, "'Search-and-Capture" of microtubules through Plus-End-Binding proteins (+TIPs)," Journal of Biochemistry, vol. 134, no. 3, pp. 321-326, 2003.

[101] A. Akhmanova and M. O. Steinmetz, "Tracking the ends: a dynamic protein network controls the fate of microtubule tips," Nature Reviews Molecular Cell Biology, vol. 9, no. 4, pp. 309-322, 2008.

[102] P. Bieling, S. Kandels-Lewis, I. A. Telley, J. van Dijk, C. Janke, and T. Surrey, "CLIP-170 tracks growing microtubule ends by dynamically recognizing composite EB1/tubulinbinding sites," Journal of Cell Biology, vol. 183, no. 7, pp. 1223-1233, 2008.

[103] Y. Komarova, C. O. de Groot, I. Grigoriev et al., "Mammalian end binding proteins control persistent microtubule growth," Journal of Cell Biology, vol. 184, no. 5, pp. 691-706, 2009.

[104] K. Takahashi, T. Tanaka, and K. Suzuki, "Directional control of WAVE2 membrane targeting by EB1 and phosphatidylinositol 3,4,5-triphosphate," Cellular Signalling, vol. 22, no. 3, pp. 510-518, 2010.

[105] A. F. Chambers, A. C. Groom, and I. C. MacDonald, "Dissemination and growth of cancer cells in metastatic sites," Nature Reviews Cancer, vol. 2, no. 8, pp. 563-572, 2002.

[106] G. Lansbergen, I. Grigoriev, Y. Mimori-Kiyosue et al., "CLASPs attach microtubule plus ends to the cell cortex through a complex with LL5 $\beta$," Developmental Cell, vol. 11, no. 1, pp. 21-32, 2006.

[107] B. Vanhaesebroeck, S. J. Leevers, K. Ahmadi et al., "Synthesis and function of 3-phosphorylated inositol lipids," Annual Review of Biochemistry, vol. 70, pp. 535-602, 2001.

[108] J. M. Haugh, F. Codazzi, M. Teruel, and T. Meyer, "Spatial sensing in fibroblasts mediated by 3' phosphoinositides," Journal of Cell Biology, vol. 151, no. 6, pp. 1269-1280, 2000.

[109] S. Srinivasan, F. Wang, S. Glavas et al., "Rac and Cdc42 play distinct roles in regulating $\mathrm{PI}(3,4,5) \mathrm{P}_{3}$ and polarity during neutrophil chemotaxis," Journal of Cell Biology, vol. 160, no. 3, pp. 375-385, 2003.

[110] P. J. van Haastert and P. N. Devreotes, "Chemotaxis: signalling the way forward," Nature Reviews Molecular Cell Biology, vol. 5, no. 8, pp. 626-634, 2004.

[111] Y. Asano, A. Nagasaki, and T. Q. Uyeda, "Correlated waves of actin filaments and $\mathrm{PIP}_{3}$ in Dictyostelium cells," Cell Motility and the Cytoskeleton, vol. 65, no. 12, pp. 923-934, 2008.

[112] G. E. Cozier, J. Carlton, D. Bouyoucef, and P. J. Cullen, "Membrane targeting by pleckstrin homology domains," Current Topics in Microbiology and Immunology, vol. 282, pp. 49-88, 2004.

[113] W. S. Park, W. D. Heo, J. H. Whalen et al., "Comprehensive identification of $\mathrm{PIP}_{3}$-regulated $\mathrm{PH}$ domains from C. elegans to $H$. sapiens by model prediction and live imaging," Molecular Cell, vol. 30, no. 3, pp. 381-392, 2008.

[114] S. A. Myers, J. W. Han, Y. Lee, R. A. Firtel, and C. Y. Chung, "A dictyostelium homologue of WASP is required for polarized F-actin assembly during chemotaxis," Molecular Biology of the Cell, vol. 16, no. 5, pp. 2191-2206, 2005.

[115] S. Suetsugu, K. Murayama, A. Sakamoto et al., "The RAC binding domain/IRSp53-MIM homology domain of IRSp53 induces RAC-dependent membrane deformation," Journal of Biological Chemistry, vol. 281, no. 46, pp. 35347-35358, 2006.

[116] P. K. Mattila, A. Pykäläinen, J. Saarikangas et al., "Missingin-metastasis and IRSp53 deform $\mathrm{PI}(4,5) \mathrm{P}_{2}$-rich membranes 
by an inverse BAR domain-like mechanism," Journal of Cell Biology, vol. 176, no. 7, pp. 953-964, 2007.

[117] K. Takahashi and K. Suzuki, "WAVE2 targeting to phosphatidylinositol 3,4,5-triphosphate mediated by insulin receptor substrate p53 through a complex with WAVE2," Cellular Signalling, vol. 22, no. 11, pp. 1708-1716, 2010.

[118] H. Miki, H. Yamaguchi, S. Suetsugu, and T. Takenawa, "IRSp53 is an essential intermediate between Rac and WAVE in the regulation of membrane ruffling," Nature, vol. 408, no. 6813, pp. 732-735, 2000.

[119] S. Suetsugu, S. Kurisu, T. Oikawa, D. Yamazaki, A. Oda, and T. Takenawa, "Optimization of WAVE2 complex-induced actin polymerization by membrane-bound IRSp53, $\mathrm{PIP}_{3}$, and Rac," Journal of Cell Biology, vol. 173, no. 4, pp. 571-585, 2006.

[120] W. Abou-Kheir, B. Isaac, H. Yamaguchi, and D. Cox, "Membrane targeting of WAVE2 is not sufficient for WAVE2dependent actin polymerization: a role for IRSp53 in mediating the interaction between Rac and WAVE2," Journal of Cell Science, vol. 121, no. 3, pp. 379-390, 2008.

[121] S. Krugmann, I. Jordens, K. Gevaert, M. Driessens, J. Vandekerckhove, and A. Hall, "Cdc42 induces filopodia by promoting the formation of an IRSp53: mena complex," Current Biology, vol. 11, no. 21, pp. 1645-1655, 2001.

[122] C. G. Saez, J. C. Myers, T. B. Shows, and L. A. Leinwand, "Human nonmuscle myosin heavy chain mRNA: generation of diversity through alternative polyadenylylation," Proceedings of the National Academy of Sciences of the United States of America, vol. 87, no. 3, pp. 1164-1168, 1990.

[123] M. Simons, M. Wang, O. W. McBride et al., "Human nonmuscle myosin heavy chains are encoded by two genes located on different chromosomes," Circulation Research, vol. 69, no. 2, pp. 530-539, 1991.

[124] A. Leal, S. Endele, C. Stengel et al., "A novel myosin heavy chain gene in human chromosome 19q13.3," Gene, vol. 312, no. 1-2, pp. 165-171, 2003.

[125] S. Morimura, K. Suzuki, and K. Takahashi, "Nonmuscle myosin IIA is required for lamellipodia formation through binding to WAVE2 and phosphatidylinositol 3,4,5triphosphate," Biochemical and Biophysical Research Communications, vol. 404, no. 3, pp. 834-840, 2011.

[126] S. Komaba and L. M. Coluccio, "Localization of myosin $1 \mathrm{~b}$ to actin protrusions requires phosphoinositide binding," Journal of Biological Chemistry, vol. 285, no. 36, pp. 2768627693, 2010.

[127] L. Plantard, A. Arjonen, J. G. Lock, G. Nurani, J. Ivaska, and S. Strömblad, "PtdIns $(3,4,5) \mathrm{P}_{3}$ is a regulator of myosin-X localization and filopodia formation," Journal of Cell Science, vol. 123, no. 20, pp. 3525-3534, 2010.

[128] W. Liang, L. Licate, H. Warrick, J. Spudich, and T. Egelhoff, "Differential localization in cells of myosin II heavy chain kinases during cytokinesis and polarized migration," BMC Cell Biology, vol. 3, no. 1, article 19, 2002.

[129] M. Guha, M. Zhou, and Y. L. Wang, "Cortical actin turnover during cytokinesis requires myosin II," Current Biology, vol. 15, no. 8, pp. 732-736, 2005.

[130] M. Lord, E. Laves, and T. D. Pollard, "Cytokinesis depends on the motor domains of myosin-II in fission yeast but not in budding yeast," Molecular Biology of the Cell, vol. 16, no. 11, pp. 5346-5355, 2005.

[131] N. A. Medeiros, D. T. Burnette, and P. Forscher, "Myosin II functions in actin-bundle turnover in neuronal growth cones," Nature Cell Biology, vol. 8, no. 3, pp. 215-226, 2006.
[132] S. A. Koestler, S. Auinger, M. Vinzenz, K. Rottner, and J. V. Small, "Differentially oriented populations of actin filaments generated in lamellipodia collaborate in pushing and pausing at the cell front," Nature Cell Biology, vol. 10, no. 3, pp. 306313, 2008.

[133] E. Urban, S. Jacob, M. Nemethova, G. P. Resch, and J. V. Small, "Electron tomography reveals unbranched networks of actin filaments in lamellipodia," Nature Cell Biology, vol. 12, no. 5, pp. 429-435, 2010.

[134] A. Yamagishi, M. Masuda, T. Ohki, H. Onishi, and N. Mochizuki, "A novel actin bundling/filopodium-forming domain conserved in insulin receptor tyrosine kinase substrate p53 and missing in metastasis protein," Journal of Biological Chemistry, vol. 279, no. 15, pp. 14929-14936, 2004.

[135] T. H. Millard, G. Bompard, M. Y. Heung et al., "Structural basis of filopodia formation induced by the IRSp53/MIM homology domain of human IRSp53," EMBO Journal, vol. 24, no. 2, pp. 240-250, 2005.

[136] A. Y. Chan, S. J. Coniglio, Y. Y. Chuang et al., "Roles of the Rac1 and Rac3 GTPases in human tumor cell invasion," Oncogene, vol. 24, no. 53, pp. 7821-7829, 2005.

[137] K. Kikuchi and K. Takahashi, "WAVE2- and microtubuledependent formation of long protrusions and invasion of cancer cells cultured on three-dimensional extracellular matrices," Cancer Science, vol. 99, no. 11, pp. 2252-2259, 2008.

[138] K. Takahashi and K. Suzuki, "WAVE2, N-WASP, and Mena facilitate cell invasion via phosphatidylinositol 3-kinasedependent local accumulation of actin filaments," Journal of Cellular Biochemistry, vol. 112, no. 11, pp. 3421-3429, 2011.

[139] S. Morimura and K. Takahashi, "Racl and stathmin but not EB1 are required for invasion of breast cancer cells in response to IGF-I," International Journal of Cell Biology, vol. 2011, Article ID 615912, 9 pages, 2011. 


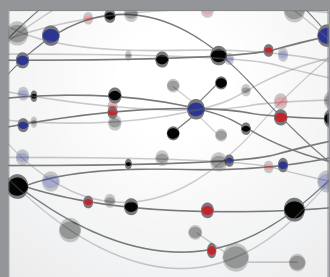

The Scientific World Journal
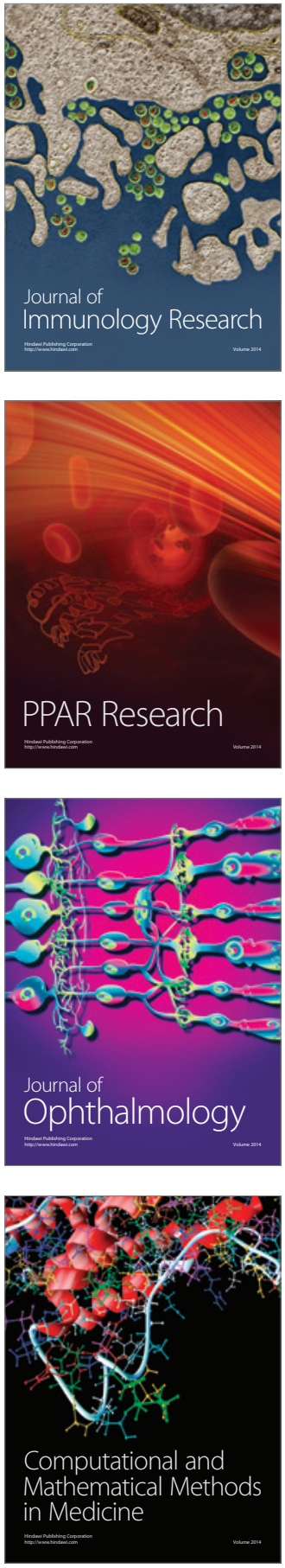

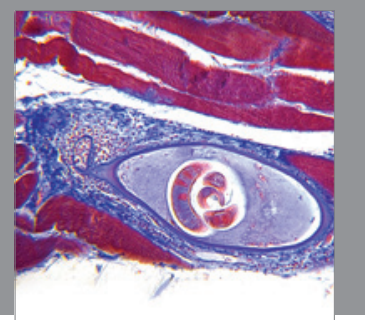

Gastroenterology

Research and Practice
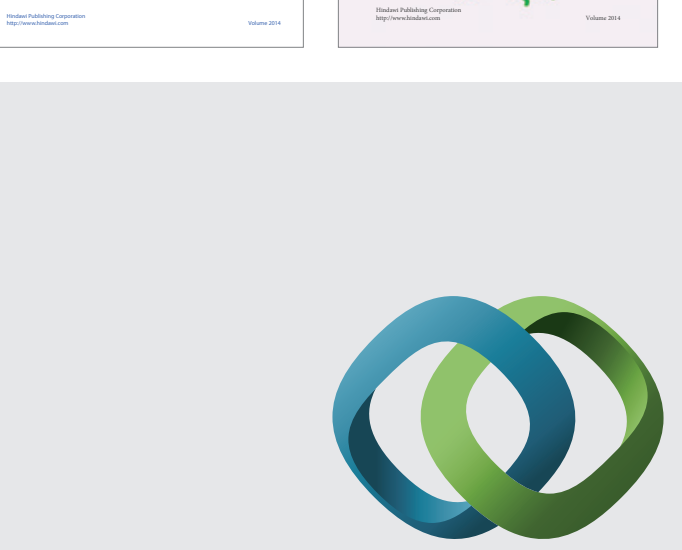

\section{Hindawi}

Submit your manuscripts at

http://www.hindawi.com
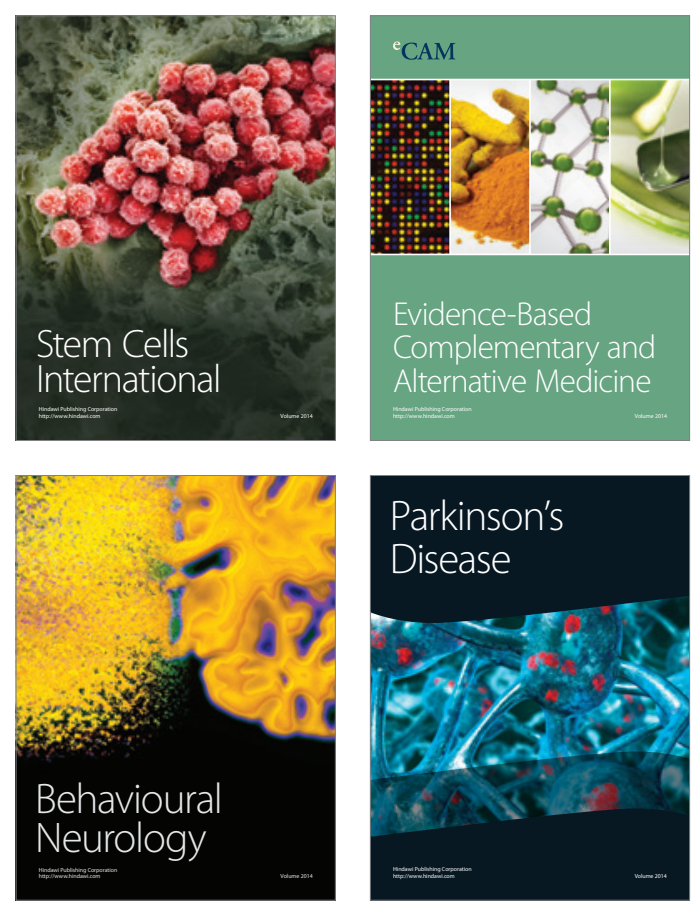

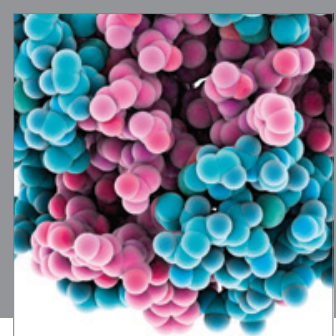

Journal of
Diabetes Research

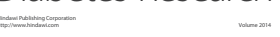

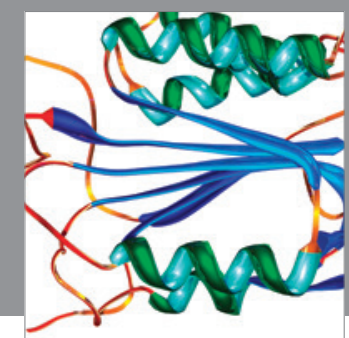

Disease Markers
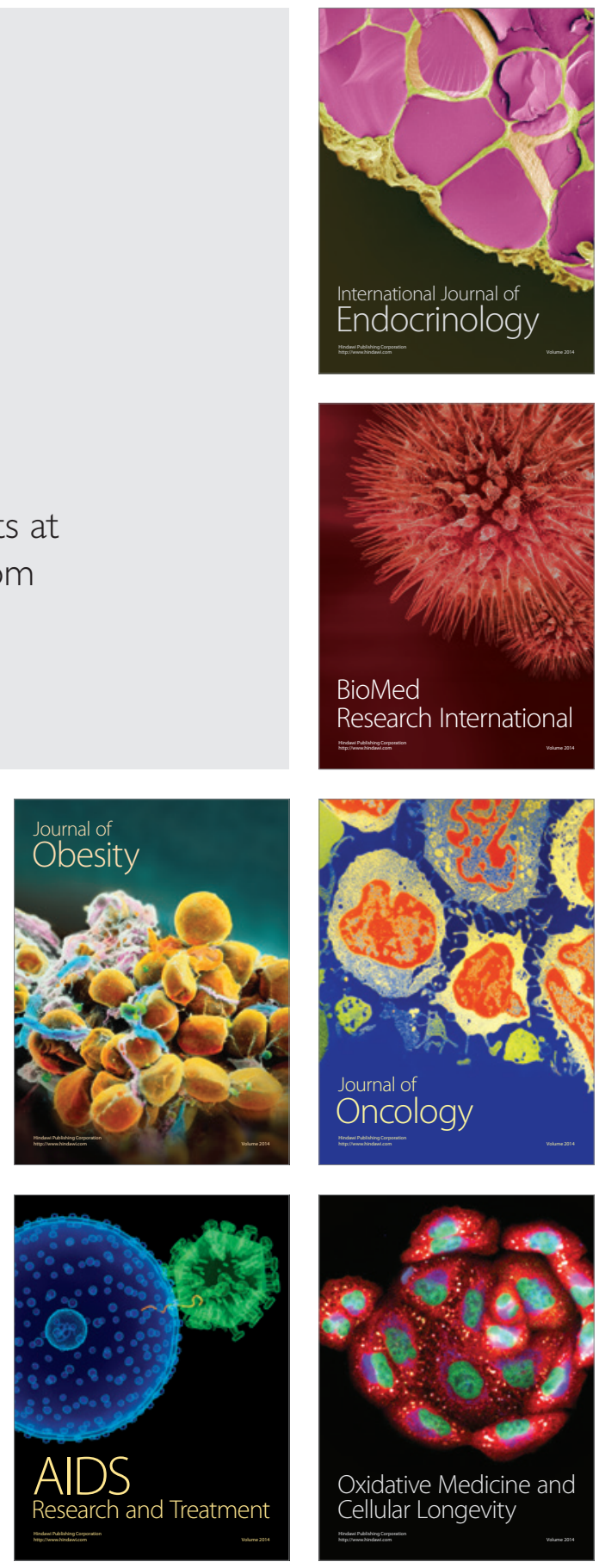